Table 1. GiYCOGEN IN HaPATIC CELLS

\begin{tabular}{|c|c|c|c|c|}
\hline \multirow{2}{*}{ Type of liver } & \multicolumn{2}{|c|}{ Dividing cells } & \multicolumn{2}{|c|}{ Non-dividing cells } \\
\cline { 2 - 5 } & $\begin{array}{c}\text { Number } \\
\text { examined }\end{array}$ & $\begin{array}{c}\text { Per cent } \\
\text { positive }\end{array}$ & $\begin{array}{c}\text { Number } \\
\text { examined }\end{array}$ & $\begin{array}{c}\text { Per cent } \\
\text { positive }\end{array}$ \\
\hline $\begin{array}{c}\text { Embryonic chick } \\
\text { (8th day of in- } \\
\text { cubation) }\end{array}$ & 80 & 71 & 78 & 76 \\
$\begin{array}{c}\text { Embryonic chick } \\
\text { (9th day of in- } \\
\text { cubation) } \\
\text { Embryonic chick } \\
\text { (9th day of in- } \\
\text { cubation) }\end{array}$ & 91 & 80 & 82 & 71 \\
$\begin{array}{c}\text { Adult rat treated } \\
\text { with butter yel- } \\
\text { low (von Gropp }\end{array}$ & 200 & 89 & 56 & 84 \\
\hline
\end{tabular}

by Lillie ${ }^{4}$, using control slides treated with saliva. Glycogen was found in the majority of non-dividing hepatic cells, mostly as $1-4$ clumps about $2 \mu$ in the longest diameter. In other cells it was in the form of fine granules and in some cases these granules were scanty. In the dividing cells, glycogen was found to have a similar distribution, and no difference could be detected in the glycogen content of dividing and non-dividing cells. To reinforce this subjective assessment the presence or absence of glycogen was determined in individual cells.

Sections were examined at a magnification of $\times 750$. Whenever hepatic cells in division were observed the presence or absence of glycogen was determined in these cells as well as in a non-dividing hepatic cell selected at random in the same field. The results for three embryonic livers are recorded in the table. In all three cases it was found that more than 70 per cent of dividing cells contained glycogen, which is significantly greater than the 42 per cent recorded by von Gropp ${ }^{1}$ in the rat liver after treatment with butter yellow. Furthermore, in the embryonic liver there is no significant difference in the proportion of dividing and non-dividing cells which contain glycogen. Thus the diminished glycogen content found in the dividing cells of the rat liver treated with a carcinogen ${ }^{1}$ and also in a hepatic tumour ${ }^{2}$ has not been found in the liver of the chicken embryo. This difference may be of importance since, in the liver, similarities have been suygested in neoplastic and embryonic tissue ${ }^{5}$.

R. J. O'CONNOR

John Burford Carlill Pathological Laboratories, Westminster School of Medicine, London, S.W.1. July 9.

'von (xropp, A., Z. Krebsforsch., 58, 438 (1952).

'Strong, I. C., and Smith, M. G., Bull. Canc., \&6, 694 (1937).

${ }^{3}$ Dalton, A. J., Anat. Rec., 68, 393 (1937). O'Connor, R. J., J. Emb. Exp. Morph., 1, 105 (1953).

${ }^{4}$ Iillie, R. D., Bull. Internat. Assoc. Med. Mus., 27, 23 (1947).

"Greenstein, J. P., "Biochemistry of Cancer", 254 (Academic Press, Inc., New York, 1947).

\section{Inhibitory Action of Cocaine}

DURING a study of the inhibitory action of cocaine on cellular respiration, we found that the oxidations of added pyruvate by brain homogenate and by the respiring yeast, Torulopsis utilis, were inhibited to a similar degree, a $0.002-M$ concentration of the drug causing an inhibition of about 50 per cent in each case. It had previously been shown, using Saccharomyces cerevisiae, that the inhibition of fermentation by cocaine could also be attributed to the blocking of pyruvate metabolism, carboxylase being inbibited ${ }^{\mathbf{1}, \mathbf{2}}$.

Further analysis with the view of discovering more precisely the site of respiratory inhibition gave results, details of which will be published elsewhere, which, when considered in conjunction with pharrnacological evidence (anti-acetylcholine effect), suggested that cocaine interfered either with the activation of acetate or with the utilization of active acetyl groups. One line of investigation to test this theory was to study the effect of cocaine on the biosynthesis of citrate from acetate.

In experiments with yeast we followed the procedure of Weinhause and Millington ${ }^{3}$, whereby citrate accumulates in an aerated suspension of starved bakers' yeast in $0.2 M$ magnesium acetate; the further metabolism of citrate being prevented by the magnesium inhibition of aconitase. Mixtures having an initial $p \mathrm{H}$ of 7 , with and without cocaine, were aerated at $30^{\circ}$. Samples were withdrawn at intervals for the estimation of eitrate by the method. of Natelson, Pincus and Lugovoy 4

In a typical experiment the following results were obtained :

\begin{tabular}{|c|c|c|c|}
\hline & \multicolumn{2}{|c|}{ Citrate, $\mu \mathrm{gm}$. per ml. yeast suspension } \\
& Time (hr.) & No cocaine & Cocaine, $0 \cdot 001 \quad M$ \\
\hline$a$ & 0 & 38 & 38 \\
$b$ & $1^{*}$ & 98 & 79 \\
$c$ & 3 & 319 & 150 \\
\hline $\begin{array}{c}\text { Synthesis during } \\
2 \text { hr. }(c-b)\end{array}$ & 221 & 71 \\
\hline
\end{tabular}

* The $p \mathrm{H}$ of the mixtures, determined electrometrically, was readjusted to 7 by addition of acetic acid.

In this experiment, during the two-hour period which falls in the most active stage of citrate synthesis, cocaine $(0.001 M)$ inhibits the accumulation of citrate by 68 per cent.

Our results show that the toxicity of cocaine towards tissue respiration lies in the ability of the drug to block the entry of two-carbon fragments into the tricarboxylic acid cycle, either by a specific inhibition of the condensing enzyme or by preventing the formation of available active acetyl groups. The latter possibility is being further investigated.

BRENDA E. RYMaN

E. O'F. WALSH

Department of Physiology,

Royal Free Hospital School of Medicine, London. July 3.

'Ryman, B. E., and Walsh, E. O'F., Nature, 187, 770 (1951).

2 Ryman, B. E., and Walsh, E. O'F., Biochem. J., 50, 570 (1952).

${ }^{3}$ Weinhause, S., and Millington, R. H., J. Amer. Chem. Soc., 69, $3089(1947)$.

4 Natelson, S., Pincus, J. B., and Lugovoy, J. K., J. Biol. Chem., 175, 745 (1948).

\section{Hydrolysis of Esters by Extracts of Insects}

O'BRIEN, in a recent communication ${ }^{1}$, said that our remarks in the two publications to which he refers ${ }^{\mathbf{2}, 3}$ could be interpreted as a statement that there was no choline esterase in adult Tribolium castaneum Hbst. or larve of Tenebrio molitor L. The relevant sentences (ref. 3, p. 496) are as follows : "Preliminary tests with preparations of whole Tribolium castaneum Hbst. and Tenebrio molitor L. failed to show any activity in hydrolysing acetyl choline. It should be pointed out that no persistent attempt was made to prepare an extract hydrolysing acetyl choline since these preparations were found to have considerable esterase activity in hydrolysing ethyl butyrate and $o$-nitrophenyl acetate. It is possible that with a 